\title{
EFFECT OF MYOGLOBIN CONCENTRATION AS SURFACE MODIFYING MOLECULE IN ULTRAFILTRATION POLYETEHRSULFONE MEMBRANE FOR LYSOZYME SEPARATION
}

\author{
Nora'aini Ali $^{1 *}$, M. T. S. Syaima ${ }^{1}$, M.Mazidah ${ }^{2}$
}

1Department of Engineering Science, Faculty of Science and Technology, University Malaysia Terengganu, 21030 Kuala Terengganu, Malaysia, ${ }^{2}$ Department of Chemical Science, Faculty of Science and Technology

University Malaysia Terengganu, 21030 Kuala Terengganu, Malaysia

*noraaini@umt.edu.my (Corresponding author)

Received on 11th January 2011, accepted in revised form 23rd March 2011.

\begin{abstract}
The application of polyethersulfone (PES) as the base polymer for the fabrication of ultrafiltration (UF) and microfiltration (MF) membrane has been vastly studied for several decades. PES had been the material of choice owing to its superior selectivity, stability, good thermal and mechanical strength. However, despite the advantages, the hydrophobicity of PES still remains to be the prime constraint for the wide utilization of this polymer as the opted fabrication material for protein application since hydrophobic surfaces is known to be very susceptible to fouling. Therefore, in this study, ultrafiltration polyethersulfone (UF-PES) membrane has been modified to render the surface with hydrophilic property. The modification is done by using a simple dip coating technique, utilizing myoglobin as the coating reagent. The $\mathrm{pH}$ of the coating solution was fixed to $\mathrm{pH} 7.0$ and the concentration of myoglobin was varied to 30,50 and $70 \mathrm{mg} / \mathrm{L}$. Membranes were named as MPH7-30, MPH7-50 and MPH7-70 with regard to the concentration of the myoglobin solution. To assess the hydrophilicity characteristics, these surface modified membranes were subjected to contact angle analysis. Membranes were also submitted to Attenuated Total Reflection - Fourier Transformed Infrared Spectroscopy (ATR-FTIR), Electro Kinetic Analyzer (EKA) and molecular weight cut-off (MWCO) evaluations. Membrane coated with myoglobin solution of $\mathrm{pH} 7.0$ with $50 \mathrm{mg} / \mathrm{L}$ concentration (MPH7-50), shows a very remarkable characteristics and performances. Owing to this, MPH7-50 membrane was applied in the ultrafiltration of lysozyme. The stability of the membrane was also estimated from the pure water flux analysis Results showed that, MPH7-50 provides a high flux $\left(21.95 \mathrm{~L} / \mathrm{m}^{2} . \mathrm{h}\right)$ as well as transmission (98\%), thus its utilization for protein components is indeed to be promising.
\end{abstract}

\begin{abstract}
ABSTRAK Aplikasi polyethersulfone sebagai polimer asas di dalam fabrikasi membran penuras ultra dan mikro telah dikaji selama berdekad. PES menjadi pilihan disebabkan oleh ciri-cirinya iaitu tahap selektiviti yang unggul, kestabilan, serta kekuatan termal dan mekanikalnya. Walaubagaimanapun, sifat hidrofobik PES masih menjadi masalah utama untuk penggunaan polimer ini secara meluas, terutamanya dalam aplikasi protein kerana permukaan yang bersifat hidrofobik mempunyai potensi untuk masalah penyumbatan membran. Oleh itu, di dalam kajian ini membran PES telah diubahsuai untuk menambahkan ciri-ciri hidrofilik kepada permukaannya menggunakan teknik pencelupan mudah dengan myoglobin. pH cecair pencelup ditetapkan pada pH7.0 dan kepekatan divariasikan kepada 30, 50 dan 70mg/L. Membran kemudiannya dinamakan sebagai MPH7-30, MPH7-50 dan MPH7-70 bergantung kepada kepekatan myoglobin. Tahap hidrofilik diperiksa mengukur sudut kebolehbasahan (contact angle). Membran juga diakses menggunakan Total Refleksi Atenuasi Spektroskopi penukaran Fourier Inframerah (ATR-FTIR) dan penganalisa elektron kinetik (EKA). Saiz molekul maksimum yang boleh ditapisi oleh membran (MWCO) juga turut diuukur. Membran yang dimodifikasi dengan myoglobin pada pH 7.0 dan berkepekatan 50 mg/L (MPH7-50), menunjukkan karakter terbaik. Membran yang diubahsuai pada keadaan ini kemudiannya digunakan untuk proses selanjutnya dalam kajian ini, iaitu ultrafiltrasi lysozyme. Kestabilan membran ini juga turut dikaji dengan mengukur kebolehtelapan membran ini terhadap bahan terlarut (air tulen). Keputusan yang diperolehi menunjukkan bahawa membran yang diubahsuai mempunyai fluks dan transmisi yang tinggi, seterusnya membuktikan keupayaan dan potensi membran ini untuk digunakan di dalam aplikasi protein adalah tinggi.
\end{abstract}

(Keywords: Ultrafiltration; Surface modification; Myoglobin; Hydrophilicity; Coating; Lysozyme)

(Kata kunci: Ultrafiltrasi, Pengubahsuaian permukaan, Myoglobin, Hidrofilisiti, Penyalutan, Lysozyme)

\section{INTRODUCTION}

In recent years, UF has become a tremendous tool for protein separation and fractionation, largely replacing the conventional methods [11]. However, despite the advantages, UF yet suffers from membrane fouling, thus restricting its practical applications is membrane fouling [4]. Fouling mainly caused the reversible 
adsorption of solutes on the membrane surface, consequently progressing to irreversible adsorption and cake build-up and leading to a flux decline over time [1]. Since the key issues of fouling are the irreversible adsorption of foulants on the membrane surface, the properties of membrane surface must be altered to minimize the adsorptive interactions of these components with the membrane surface $[10,8$, 9]. Among the approaches towards overcoming the fouling problem, membrane surface modification has shown its unique advantage in terms of understanding and affecting the fouling process at molecular level. Surface modification is the most versatile way to change the surface properties of the membrane while preserving it macroporous structure.

For years, many researchers had extensively devised various strategies to modify membrane surfaces, [12, $15,3,14,7]$ which can be generally divided into two groups which are: grafting and coating. Compared to grafting which consumes a large production cost, coating is more favorable, owing to its easy implementations since it can be performed in existing membrane installations, without requiring any additional processing [1]. In our previous work, a dip coating method for surface modification of PES-UF membrane had been developed. Effects of myoglobin $\mathrm{pH}$ on the coating degree, membrane traits and performance have been well studied and the roles of coating solution properties on membrane characteristic have been proved to be vital.

Therefore, in this research, a more detail investigation of the effects of coating material properties on the membrane viability was carried out. Coating solution concentration (i.e. myoglobin) was selected as the parameter of study and was varied in the predetermined ranges.

\section{MATERIALS AND METHOD}

\subsection{Materials}

Polyethersulfone (Radel A-300) was purchased from BP Amoco, USA with molecular weight of repeat unit $232.26 \mathrm{~g} / \mathrm{mol}$ as the membrane-forming polymer. Solvent used is 1-Methyl-2-Pyrrolidone with analytical purity $99.7 \%$, NMP and was purchased from Fluka, Germany and non-solvent used is water. Myoglobin (from horse heart, MW 17kDa, $\mathrm{p} I=7.0$ ) was used as the coating material in surface modification process. Lysozyme (from chicken egg white, MW 14kDa, $\mathrm{p} I=11.0$ ) was applied in protein ultrafiltration studies. For molecular weight cut-off (MWCO) estimation, Trypsin (23kDa), Pepsin $(35 \mathrm{kDa})$, Ovalbumin $(45 \mathrm{kDa})$ and BSA $(67 \mathrm{kDa})$ were implied. All proteins were supplied by Sigma Aldrich and were well dispersed in the respective buffer prior to any use. Other organic solvents were reagent grade and used without further purification.

\subsection{Apparatus and procedure}

\subsubsection{Membrane fabrication}

The flat sheet PES membranes were fabricated using the phase inversion techniques using semi-automated electrically casting machine (Atrish Techinic Services Sdn. Bhd). The percentage of PES in the dope was fixed to $15 \%$. The prepared dope was then poured onto a glass plate and spread with a casting knife at an approximately constant shear rate $200 \mathrm{~s}^{-1}$. The glass plate was quenched immediately in a first coagulation bath to induce polymer precipitation. Then, membranes were post-treated in methanol as the second coagulation bath to ensure the excess solvent, water soluble polymer were totally removed and to strengthen the molecules structure built in the membrane. The 15-M membranes were then air dried.

\subsubsection{Membrane surface modification}

The PES supporting membranes was rinsed with phosphate buffer prior to further usage. Myoglobin solution was fixed to $\mathrm{pH} 7.0$ and was varied to three different concentrations of 30,50 and $70 \mathrm{mg} / \mathrm{L}$. The clean membrane was then dipped in the prepared myoglobin solution for 12 hours to ensure the formation of myoglobin film onto the outer layer of the membrane. After the immersion process, all coated membranes were air dried and compacted for 20 minutes. The produced membranes were designated as MPH7-30, MPH7-50 and MPH7-70 with regard to the concentration of the coating solution.

\subsubsection{Surface chemical composition evaluation}

Each individual coated membrane was subjected to Attenuated total reflection-Fourier transform infrared spectroscopy analysis for the determination of surface chemical composition. ATR-FTIR is an important tool able to identify the types of chemicals from its chemical bonds (i.e. functional groups) [2] thus, the successfulness of myoglobin coating onto the membrane surface could be detected. Plane polarized infrared spectra of membrane (parallel and perpendicular to shear direction) were determined by a diffuse reflectance infrared Fourier transform spectrometer PerkinElmer, Spectrum 100. A total of 16 scans were recorded at $4.0 \mathrm{~cm}-1$ resolution.

\subsubsection{Contact angle measurement}

The hydrophilicity of the membranes was measured by sessile drop method using face contact angle (Model CA-A Face Kyowa Kaimenkagaku Co. Ltd). Contact angle is the quantification of the degree of membrane hydrophilicity. The lower contact angle 
value represent the higher hydrophilicity while the vice versa situation indicates the lower hyrdrophilicity.

\section{[]2.2.5 Molecular weight cut-off (MWCO) assessment}

The molecular weight cut-off (MWCO) of this pretreated membrane was determined by measuring the separation values of various proteins with different molecular weight (MW). A logarithmic graph of the rejection of these protein series versus their MW was plotted and MWCO was calculated based on $90 \%$ of protein retention.

\subsubsection{Surface charge characterization}

Streaming potential measurements were made using the SurPASS Electro-kinetic Analyzer (Anton-Paar $\mathrm{KG}$, Graz, Austria). A flat plate module measuring cell with the dimension of $55 \mathrm{~mm} \times 25 \mathrm{~mm}$ was used. Potassium chloride was employed as the electrolyte solution. Zeta potentials were calculated from the measured streaming potentials using the FairbrotherMastin (F-M) equation [13]:

$$
\frac{\Delta \varphi}{\Delta \mathrm{P}}=\zeta \frac{\left(\varepsilon_{0} \varepsilon \mathrm{r}\right)}{\left(\eta \frac{\lambda_{\mathrm{h}}}{\left.\lambda_{0}\right)}\right.} \quad \frac{\left(\mathrm{R}_{\mathrm{h}}\right)}{\mathrm{R}}
$$

Here is the measured electrical (streaming) potential in the flow cell, $\Delta \mathrm{P}$ is the applied pressure in the cell used to force the electrolyte to flow over the charged surfaces, $\varepsilon_{0}$ is the vacuum permittivity, $\varepsilon r$ is the relative dielectric constant of the electrolyte solvent,

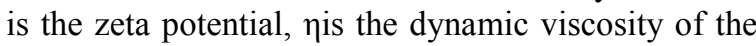
electrolyte, $\lambda_{0}$ is the bulk conductivity of the circulating electrolyte, $\lambda_{\mathrm{h}}$ is the electrical conductivity of the highly saline reference solution $(100 \mathrm{mM} \mathrm{KCl})$, $\mathrm{R}_{\mathrm{h}}$ is the measured electrical resistance across the flow channel filled with the highly saline reference solution, and $\mathrm{R}$ is the measured electrical resistance across the flow channel filled with the normal experimental electrolyte [5].

\subsubsection{Ultrafiltration experiment}

The mechanism of lysozyme transportation though the myoglobin modified PES-UF membrane was assessed using a $300 \mathrm{ml}$ processing volume dead end cell with a membrane with an effective area of 14.6 $\mathrm{cm}^{2}$. The transmembrane pressure was maintained using pure nitrogen gas. Pure water permeation and protein filtration were tested for each membrane. Feed pressure was controlled in the range of 1-5 bars and $10 \mathrm{~mL}$ of permeate was collected for each run. Nitrogen gas was used to pressurize the system and to maintain the transmembrane pressure. UV-Vis Spectrophotometer was used to monitor the presence of protein in the feed and permeate. Then, the flux and transmission graph versus pressure was plotted at the end of the experiment.

\section{RESULTS AND DISCUSSION}

\subsection{Effect of coating solution concentration on membrane characteristics}

3.1.1 Surface chemical composition (ATR-FTIR)

The influence of coating solution concentration on the extent of myoglobin adsorption on the membrane was evaluated by FTIR. From the plotted FTIR spectra (Figure 1), the typical infrared regions for PES (bands (a) to (e) in Figure 3C) as such aromatic bands at $\sim 1578 \mathrm{~cm}-1$ and $\sim 1485 \mathrm{~cm}-1$ from the benzene ring [10] $1240 \mathrm{~cm}-1$ from ether groups and $1040 \mathrm{~cm}-1$ from PES sulfonic groups [17, 6] are clearly observed. Apparently, the bands in $3700 \mathrm{~cm}-1$ to $2500 \mathrm{~cm}-1$ (O-H and N-H), $2900 \mathrm{~cm}-1$ to $2800 \mathrm{~cm}-1$ (H-bonds) and $1720 \mathrm{~cm}-1$ to $1730 \mathrm{~cm}-1$ (spectra for AA from carbonyl groups) all which denotes the peaks of (proteins) myoglobin, is highly intensified in MPH7-50 membrane.

This might be the first indicator that signify that, the highest adsorption of myoglobin occur when MPH7 membranes were treated with coating solution having concentration of $50 \mathrm{mg} / \mathrm{L}$. However, auxiliary analysis on hydrophilicity, surface charge, molecular weight cut-off (MWCO), pure water permeability (PWP) and protein filtration will be conducted to further verify this conclusion.

\subsubsection{Hydrophilicity determination}

The contact angle measurement for MPH7-30, MPH7-50, and MPH7-70 membranes is depicted in Table 1. Although all the membranes were immersed in the myoglobin solution bears the same $\mathrm{pH}$, there is slightly a big difference in the contact angle when they were further modified by the myoglobin solution having various concentrations. This fairly suggesting that concentration of the coating material do plays a main role in membrane modification process. The smallest contact angle is attained for MPH7-50 membrane, which is 45.2. However, when the concentration of myoglobin solution is increased to $70 \mathrm{mg} / \mathrm{L}$, there is a dramatic increase in the contact angle value, implying that the membrane properties is gradually changes to the hydrophobic characteristic of the original un-modified PES membrane when concentration of the coating solution is amplified to more than $50 \mathrm{mg} / \mathrm{L}$. The attained results had indirectly reveals that, $50 \mathrm{mg} / \mathrm{L}$ is the optimum myoglobin concentration for membrane surface modification. This will nevertheless proceed by the MWCO analysis to further validate the conclusion. 


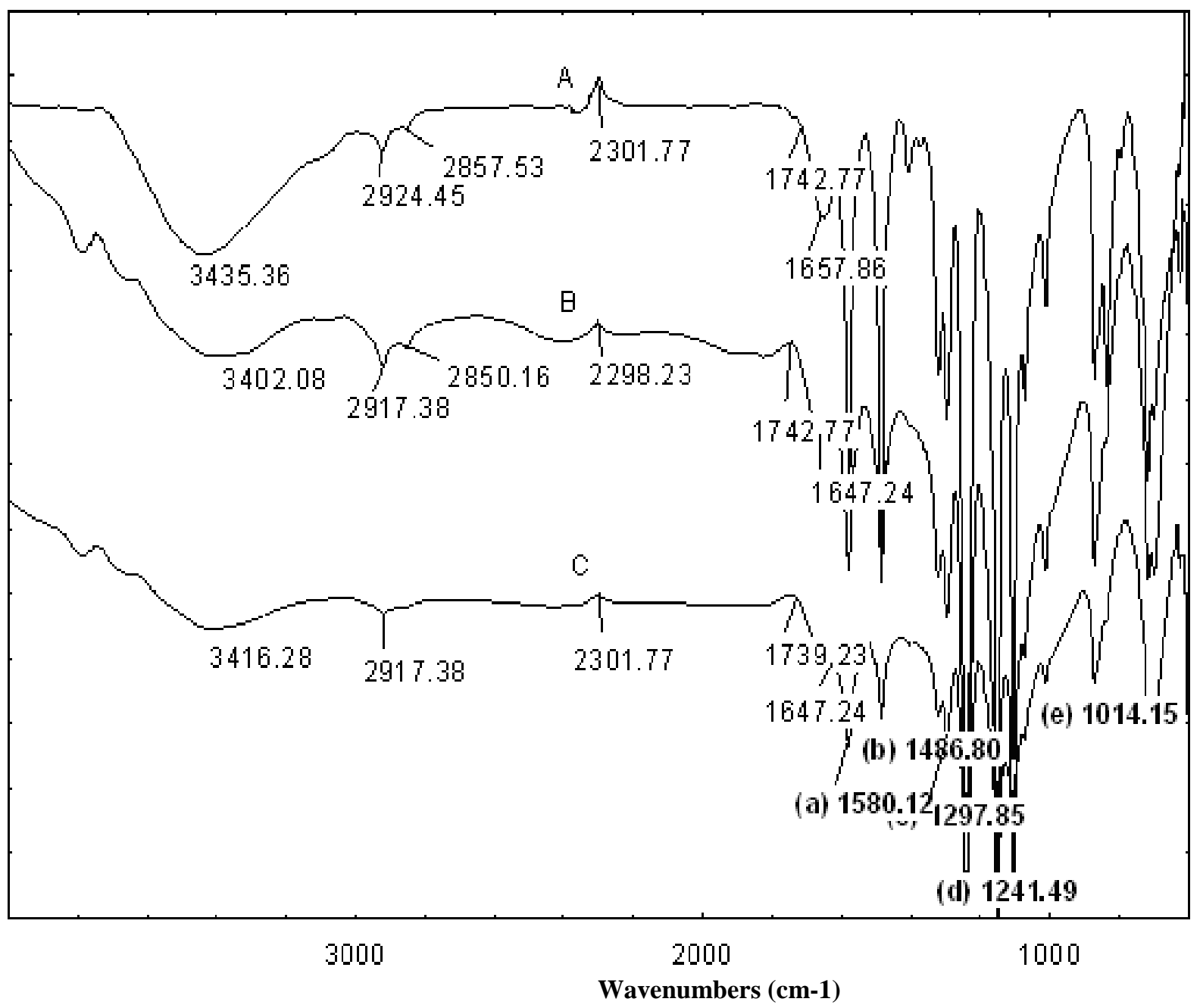

Figure 1: FTIR of native and membranes modified with different $\mathrm{pH}$ of coating solution

(A) MPH7-50, (B) MPH7-30 and (c) MPH7-70

\subsubsection{Hydrophilicity determination}

The contact angle measurement for MPH7-30, MPH7-50, and MPH7-70 membranes is depicted in Table 1. Although all the membranes were immersed in the myoglobin solution bears the same $\mathrm{pH}$, there is slightly a big difference in the contact angle when they were further modified by the myoglobin solution having various concentrations. This fairly suggesting that concentration of the coating material do plays a main role in membrane modification process. The smallest contact angle is attained for MPH7-50 membrane, which is 45.2. However, when the concentration of myoglobin solution is increased to $70 \mathrm{mg} / \mathrm{L}$, there is a dramatic increase in the contact angle value, implying that the membrane properties is gradually changes to the hydrophobic characteristic of the original un-modified PES membrane when concentration of the coating solution is amplified to more than $50 \mathrm{mg} / \mathrm{L}$. The attained results had indirectly reveals that, $50 \mathrm{mg} / \mathrm{L}$ is the optimum myoglobin concentration for membrane surface modification.
This will nevertheless proceed by the MWCO analysis to further validate the conclusion.

Table 1 Contact angles for all membranes

\begin{tabular}{cc}
\hline Membranes ID & Contact angle \\
\hline MPH7-50 & 45.2 \\
MPH7-30 & 60.0 \\
MPH7-70 & 66.0 \\
Native & 85.5 \\
\hline
\end{tabular}

\subsubsection{Molecular weight cut-off (MWCO)}

Table 2 represents the MWCO of MPH7-30, MPH750 and MPH7-70 membranes. MPH7-50 posses the lowest MWCO, which is $17 \mathrm{kDa}$. This is likely due to the highest adsorption of myoglobin for the MPH750 , as illustrated in the preceding FTIR result. A 
unique trend could be observed for MPH7-70, where its MWCO increase up to $36 \mathrm{kDa}$, almost similar to the MWCO of the un-modified membrane $(39 \mathrm{kDa})$. In other words, it proposed that, increasing the myoglobin concentration to $70 \mathrm{mg} / \mathrm{L}$ will increase the MWCO up to the level of the MWCO of the native membrane. Thus, it is postulated that, the membrane surfaces were completely coated after treatment with $50 \mathrm{mg} / \mathrm{L}$ myoglobin concentration and further thickening of myoglobin beyond this concentration will no longer gives any effects to the characteristics. Instead, it will be changed to the original, unmodified membrane.

These claims were strengthened by the earlier result from contact angle measurement, which shows that the contact angle of the membranes increase considerably to the contact angle of the virgin membrane after modified with $70 \mathrm{mg} / \mathrm{L}$ coating solution. In addition, the results from ATR-FTIR also portrayed that, the intensities band of myoglobin for MPH7-70 membrane were significantly reduced.

This strongly proved that, the presence of myoglobin on the membrane surface was decreased after the treatment with $70 \mathrm{mg} / \mathrm{L}$ of solution. This whole finding signify that, the region of independence has been reached at $50 \mathrm{mg} / \mathrm{L}$, in which the range of concentration of added proteins above which surface saturation is reached and further binding are negligible. In short explanation, myoglobin will be leached out instead of accumulating on the membranes surface. [16].

Table 2: MWCO for all membranes

\begin{tabular}{lc}
\hline Membranes ID & MWCO $(\mathrm{kDa})$ \\
\hline MPH7-50 & 17 \\
MPH7-30 & 27 \\
MPH7-70 & 34 \\
Native & 39 \\
\hline
\end{tabular}

\subsubsection{Membrane surface charge}

The obtained zeta potential is lowest for MPH7-70 ($0.0014)$, coherently with the discovery of the earlier scholars who declared that, increasing the coating solution concentration will lower the surface charge, as more myoglobin is adsorbed to cover the surface. However, the discrepancies in the surface charge for the three membranes are not significant and almost negligible.
Table 3 Zeta potential for all membranes

\begin{tabular}{cc}
\hline Membranes ID & Zp \\
\hline MPH7-50 & 0.000 \\
MPH7-30 & -0.005 \\
MPH7-70 & -0.0014 \\
\hline
\end{tabular}

3.2 Effect of coating solution pH on membrane performance

3.2.1 Pure water flux and permeability

Permeability coefficient determination was implemented for MPH7-30, MPH7-50 and MPH7-70 membranes. All the plotted graphs (Figure 2) show a linear profile, indicating that the pure water flux is directly proportional to the applied pressure. At applied pressure of 1 bar, all membranes gave the lowest flux and increased of flux occurred linearly as the pressure increased up to 5 bar. However, from the PWP results represented in Table 4, it shows that, the PWP of the MPH7-70 membrane does not lie in the range of permeability values for UF membrane specified for protein separation.

The highest PWP is obtained for MPH7-50 membrane, which is $21.95 \mathrm{~L} / \mathrm{m} 2$.h.bar.

Table 4: Pure water permeability (PWP)

\begin{tabular}{cc}
\hline Membranes ID & PWP (L/m².h.bar $)$ \\
\hline MPH7-30 & 16.99 \\
MPH7-50 & 21.95 \\
MPH7-70 & 8.292 \\
NATIVE & 9.6797 \\
\hline
\end{tabular}

\subsubsection{Lysozyme separation}

The flux and transmission graphs for all three types of membranes are plotted in Figure 3 (a) \& Figure 3 (b). MPH7-50 acquires the highest transmission of lysozyme protein, which is $98 \%$. This is reliable owing to the highest flux value of MPH7-50. Moreover, the above mentioned result of PWP also shows that, the PWP for the MPH7-50 is of maximum value compared to MPH7-30 and MPH770.

The greatest productivity achieved for MPH7-50 pointed that, this membrane is endowed with the both the suitable porosity and hydrohilicity for lysozyme separation. Overall results on membrane characterization, water permeability and protein filtration proved that the most suitable condition for 


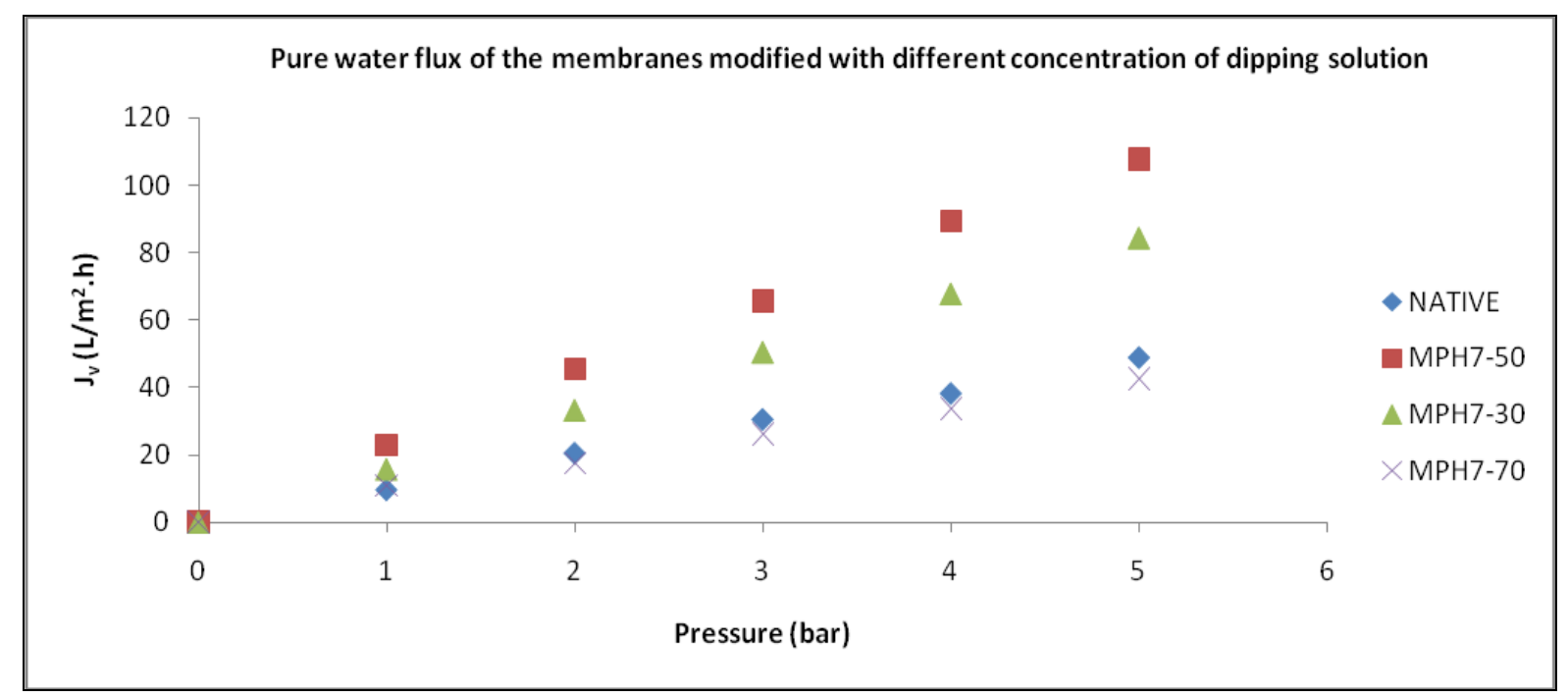

Figure 2: PWF at different operating pressure

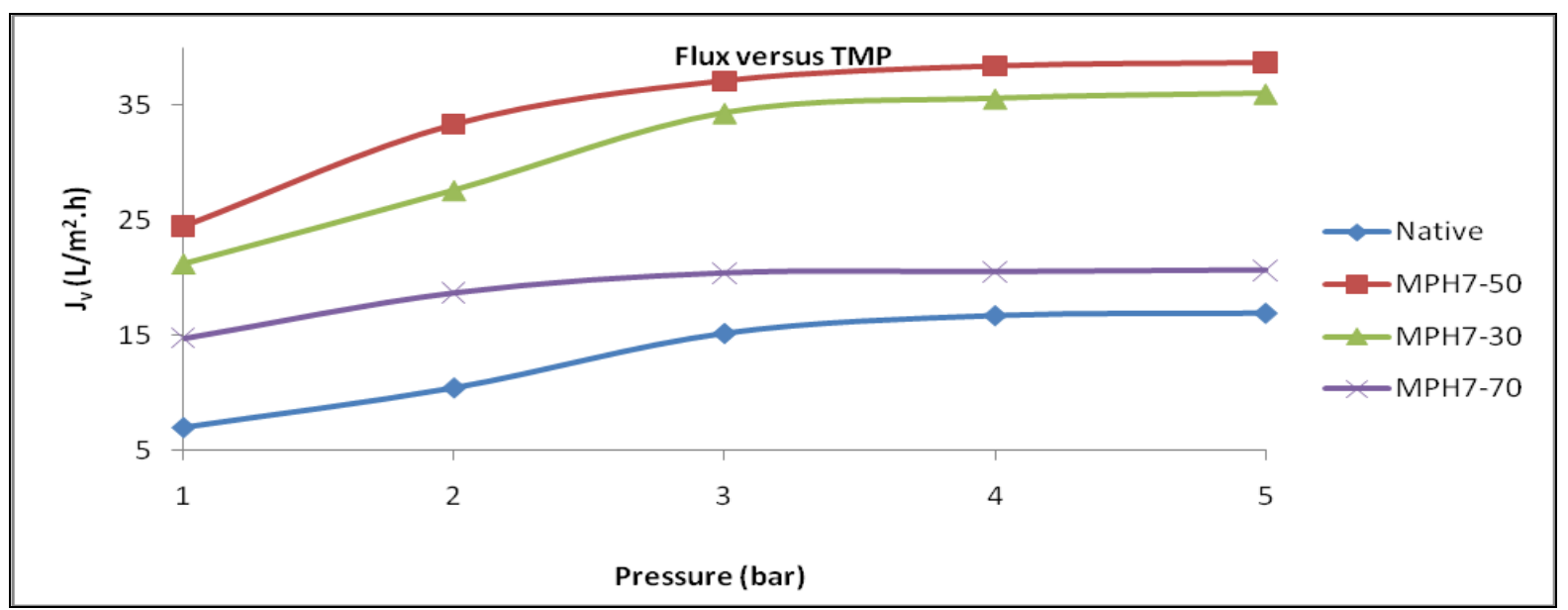

(a)

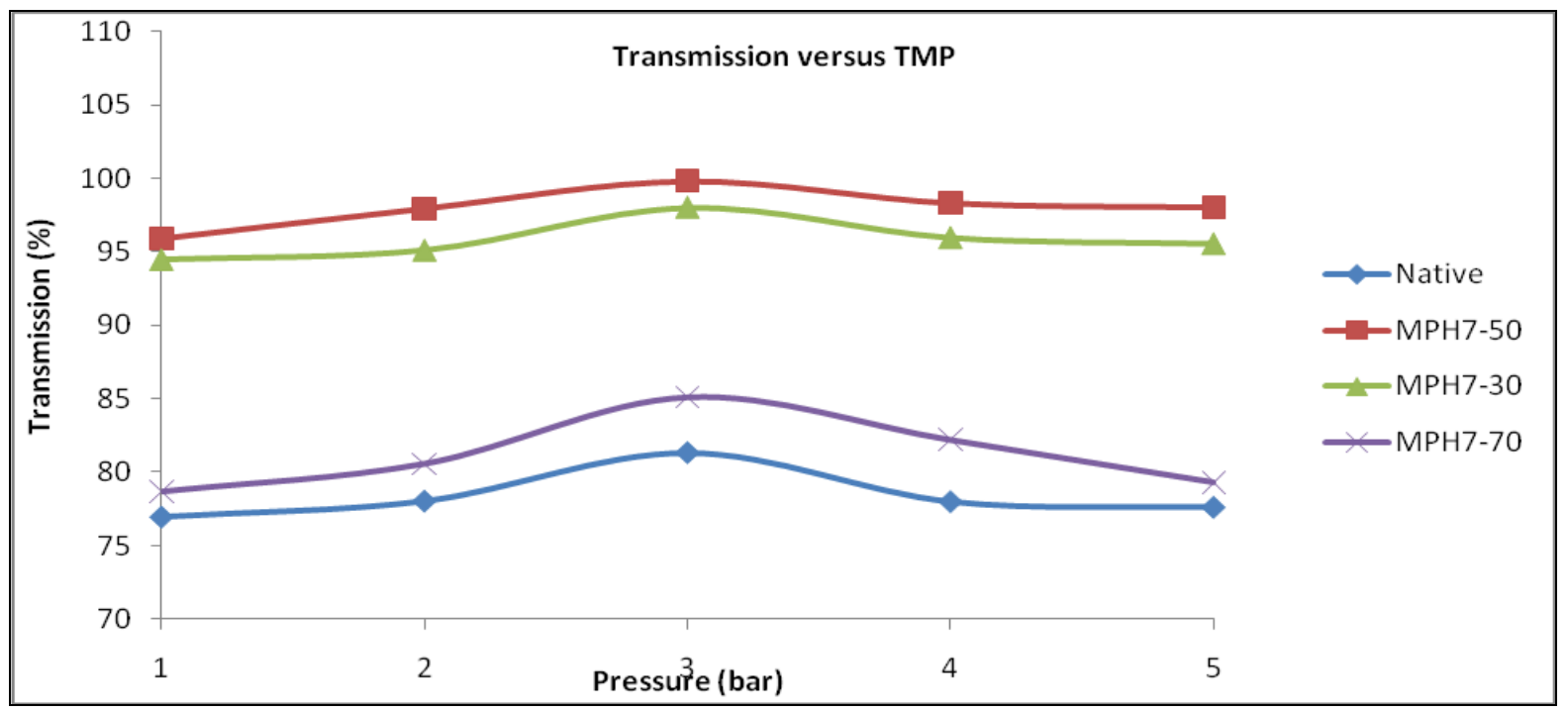

(b)

Figure 3 (a): Fluxes and (b) transmission of proteins for membranes modified with different concentration of myoglobin 
modification solution is $\mathrm{pH} 7.0$ with concentration of $50 \mathrm{mg} / \mathrm{L}$.

\section{CONCLUSION}

In summary, the sieving characteristics of PES-UF membrane have been enhanced render to the formation of myoglobin layer on the membrane surface. The development of myoglobin coating was readily obtained by 12 hours dipping of PES-UF membranes in the solution of myoglobin followed by a rinse step. The level of myoglobin adsorption and deposition on the top layer of membrane were controlled by adjusting parameters such as the concentration of the coating solution. This method of surface modification is relatively simple, since it does not require any complicated equipment, or elaborate material design.

The modification could be done at the end of membrane fabrication without requiring additional processing steps or extensive used of chemicals. Additionally, the used of complex apparatus could be avoided, since this technique only involve a simple immersion of the membranes in the myoglobin solutions in contrast to grafting which need UV irradiation and specialized photo chemicals process. Furthermore, myoglobin is commercially and widely avalaible compared to the other type of modifier agents such as polyethylene glycol (PEG) or other types of hydrophilic polymers. biodegradable, and biocompatible, subsequently expected to be environmentally benign. We really hope that this work can provide some facile approach toward the development of low-fouling, highly endurance membrane, in the same time serve as a reference in lysozyme purification, especially in the fractionation of this protein from the real biological solutions.

\section{ACKNOWLEDGMENT}

The authors would like to thank all the individuals, involves directly or indirectly in this project, for their academics and technical supports. Utmost appreciation is dedicated to the Ministry of Science, Technology and Innovation (MOSTI) Malaysia for the financial support. Praises also goes to Universiti Malaysia Terengganu, (UMT) Malaysia for the workplace and Malaysian Institute of Nuclear Technology (MINT) for their permission in using contact angle analyzer.

\section{REFERENCES}

[1] Ba, C., Ladner, D.A., Economy, J (2010). Using polyelectrolyte coatings to improve fouling resistance of a positively charged nanofiltration membrane. Journal of Membrane Science 347; 2010: 250-259

Also, being a type of protein and derived from natural source, it was expected to be non-toxic,

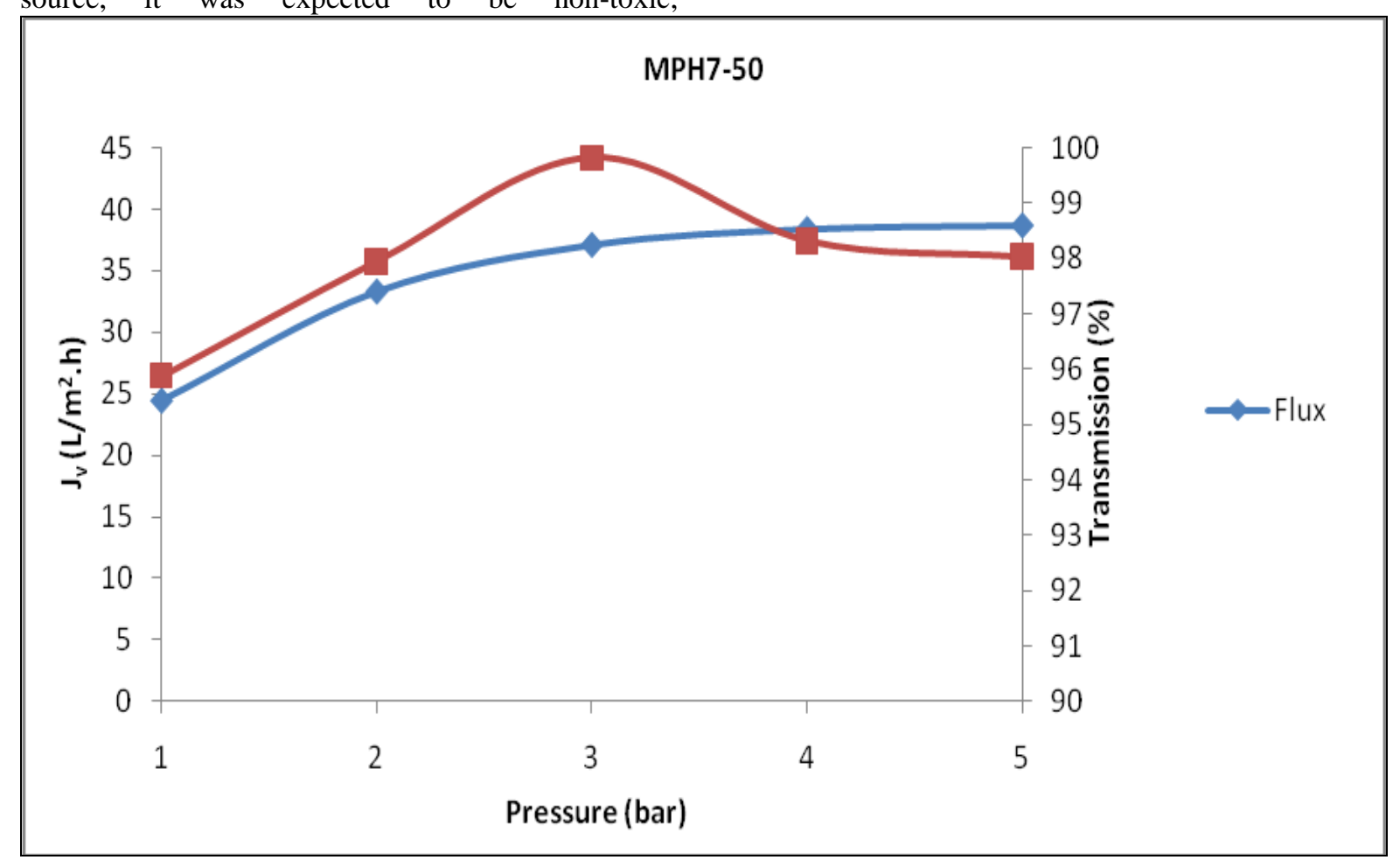

Figure 4: Flux and transmission for MPH7-50 membrane 
[2] Bolong N. , Ismail A.F. , Salim M.R. , Matsuura T. (2008). Miscibility characteristic of PES hollow fiber membranes with chargedsurface modifying macromolecules (cSMM) for water separation applications. Jurnal Teknologi, 2008; 49: 123-132 .

[3] Hasegawa T., Iwasaki Y., Ishihara K. (2001). Preparation and performance of proteinadsorption resistant asymmetric porous membrane composed of polysulfone/phospholipids polymer blend. Biomaterials 2001; 22: 243-251.

[4] Huisman I.H., Pradanos P., Hernandez A. (2000). The effect of protein-protein and protein-membrane interactions on membrane fouling in ultrafiltration. Journal of Membrane Science 2000;179: 79-90.

[5] Hurwitz G., Guillen G.R., Hoek E.M.V. (2010). Probing polyamide membrane surface charge, zeta potential, wettability, and hydrophilicity with contact angle measurements. Journal of Membrane Science 2010; 347: 250-259.

[6] Jung B. (2004). Preparation of hydrophilic polyacrylonitrile blend membranes for ultrafiltration. Journal of Membrane Science 2004; 229:126-139.

[7] Lin Y.C., Brayfield A.C., Gerlach J.C., Rubin J.P., Marra K.G. (2009). Peptide modification of polyethersulfone surfaces to improve adipose-derived stem cell adhesion. Acta Biomaterialia 2009; 5: 1416-1424

[8] Reddy A.V.R., Mohan D.J., Bhattacharya A., Shah V.J., Ghosh P.K. (2003). Surface modification of ultrafiltration membranes by preadsoprtion of a negatively charged polymer. I. Permeation of water soluble polymers and inorganic salt solutions and fouling resistance properties (2003). Journal of Membrane Science 2003; 214: 211-221

[9] Shi Q., Su Y., Zhao W., Li C., Hu Y., Jiang Z., Zhu S. (2008). Zwitterionic polyethersulfone ultrafiltration membrane with superior antifouling properties. Journal of Membrane Science 2008; 319: 271-278.
[10] Susanto H., Ulbricht M. (2009). Characteristics, performance and stability of polyethersulfone ultrafiltration membrane prepared by phase separation method using different macromolecular additves. Journal of Membrane Science 2009; 327: 125-135

[11] Susanto H., Stahra, N., Ulbricht M. (2009). High performance polyethersulfone microfiltration membrane having high flux and stable hydrophilic properties. Journal of Membrane Science 2009;342:153-164.

[12] Taniguchi M., Pieracci J., Samsonoff W.A., Belfort G. (2003). UV assisted graft polymerization of synthetic membranes: mechanistic studies. Chemical Materials 2003; 15: 3805-3812.

[13] Temmel S., Kern W., Luxbacher T. (2006). Zeta potential of photochemically modified polymer surfaces, Progress of Colloid and Polymers Science 2006; 132: 54

[14] Wan Y., Lu J., Cui Z. (2006). Separation of lysozyme from chicken egg white using ultrafiltration . Separation and Purification Technology 2006; 48: 133-142.

[15] Ye S.H., Watanabe J., Iwasaki Y., Ishihara K. (2003). Antifouling blood purification membrane composed of cellilose acetate and phospolipid polymer. Biomaterials 2003; 24: 4143-4152.

[16] Wang C., Yang F., Meng F., Zhang H., Xue Y., Fu G. (2010). High flux and antifouling filtration membrane based on non-woven fabric with chitosan coating for membrane bioreactors. Article in Press, Bioresource Technology.

[17] Yu H., Cao Y., Kang G., Liu J., Li M., Yuan Q. (2009). Enhancing antifouling property of polysulfone ultrafiltration membrane by grafting zwitterionic copolymer via UVinitiated polymerization. Journal of Membrane Science 2009; 342: 6-13. 